\title{
CULTURAL DIALOG AS A MULTI-COMPONENT MEANS OF FORMING A TOLERANT PERSONALITY
}

\author{
Alfira S. Hajrullina ${ }^{1}$ \\ Gumar F. Dautov ${ }^{2}$ \\ Gulnaz R. Mugtasimova ${ }^{3}$ \\ Nasima A. Mukimova ${ }^{4}$
}

Abstract: This paper considers the possibilities of cultural dialog in the formation and education of a tolerant personality. Modern educational paradigms are studies in terms of humanization and humanitarization of education; creative use of tolerance; issues of formation of moral values based on meaningful value bases of human life and society; value attitude to a person; search for the meaning of life through the characters on the example of the works of Razil Valeev. The analysis of scientific literature allows identifying a number of its features: the upbringing of a person as a subject of action; finding a dominant inside the life itself; the formation of a tolerant personality in the context of a cultural dialog, and others.
The authors analyze the prose of the famous Tatar writer Razil Valeev. The research complements the theoretical space of the actual pedagogical problem, makes it possible to consider the research in a practical aspect. This is because the proposed model can be used by teachers, school teachers at lessons of national pedagogy, native literature and extracurricular activities for educational work.

Keywords: national pedagogy; Tatar literature; moral values; heroes; education; dialog; tolerance; culture; multicultural literature.

\section{Introduction}

\footnotetext{
${ }^{1}$ Yelabuga Institute of the Kazan Federal University, Yelabuga, Russia. E-mail: alfira7171@mail.ru

${ }^{2}$ Yelabuga Institute of the Kazan Federal University, Yelabuga, Russia. E-mail: capslock78tat@mail.ru

${ }^{3}$ Kazan (Volga region) Federal University, Kazan, Russia. E-mail: gulnaz-72@ mail.ru

${ }^{4}$ Sterlitamak branch Federal State Budgetary Educational Institution of Higher Education «Bashkir State University», Sterlitamak, Russia. E-mail: nasima1974@yandex.ru
} 


\section{I}

\section{GEN NERO E}

INTERDISCIPLINARIDADE

The global community sets the goal for the Russian education system, which is the education of a personality with the planetary thinking who is able to consider themselves not only as a representative of the native culture living in a specific country but a citizen of the world, perceiving themselves as bearers of their own and foreign cultures. This predetermines the need to form a tolerant personality in students as the most important component in the education system (Vasilyeva, n.d.).

The purpose of this study is to identify the theoretical basis and experimental verification of the effective formation of a tolerant personality through the cultural dialog of the literary characters.

The research tasks were formulated as follows:

- to reveal and supplement the essence of forming a tolerant personality in students during the study of the works of Razil Valeev.

- to develop a model for the formation of a tolerant personality in students by means of a cultural dialog as a multi-component means of communication.

- to carry out an experimental test of the effectiveness of forming a tolerant
Vol $^{\circ} 02$ | nº 01 | ISSN: 2675-7451

https://www.periodicojs.com.br/index.php/gei/index

personality in students during the study of literary works.

The paper uses scientific papers on the formation of tolerance among schoolchildren and students (B. S. Gershunsky, A.V. Dmitriev, L. M. Drobizheva, M. S. Kagan, G. I. Kozyrev, N. Yu. Kudzieva, V. A. Lectorsky, I. L. Pluzhnik et al.); cultural dialog theory (V. S. Bibler, S. Yu. Kurganov, R. F. Mukhametshina et al.); theory of modeling the formation of personality and professional activity (N. V. Kuzmina, Yu. A. Lavrikov, V. A. Slastenin, E. E. Smirnova, I. E. Yarmakeev etc.), and others.

\section{Materials and methods}

The following methods were used for checking the initial provisions: theoretical methods (study and analysis of scientific literature systematic analysis of the phenomena); survey methods (questionnaire - a method of mass collection of information, conversation - a dialog on a preplanned basis, interviewing - a clear statement of questions, unfinished sentences), diagnostic methods (observation, survey, conversation, questioning, testing, selfassessment); monographic method of research of overall experience (analysis of fiction, analysis of the results of 


\section{I}

GEN NERO E

INTERDISCIPLINARIDADE

educational and extracurricular activities of students, ranking, expert survey); experimental methods (stating, forming and control stages of pedagogical experiment); pedagogical modeling; and mathematical statistics, etc.

A situational method was organized to study the mentality of Razil Valeev's characters.

The study was conducted in several interrelated stages:

Stage 1 - analysis and generalization of scientific literature on the research problem;

- specification of the general goal in the system of research tasks and formulation of the experimental hypothesis;

Stage 2 - selection and organization of didactic materials of the national-regional component, development of pedagogical technology for implementing a complex of didactic tools for the cultural dialog, as a multicomponent means of forming a tolerant personality;

Stage 3 - conducting a pedagogical experiment, carrying out initial and final diagnostic measurements in experimental and control samples, statistical processing of the obtained empirical data, qualitative comparative interpretation of the results of
$\operatorname{Vol}^{\circ} 02\left|n^{\circ} 01\right|$ ISSN: 2675-7451

https://www.periodicojs.com.br/index.php/gei/index

experimental training in the form of mathematical analysis;

- generalization and formulation

of conclusions based on the results of the study.

The experimental base of the research was the premises of Elabuga Institute of Kazan (Volga) Federal University and students of the Department of Philology and History. The sample population consisted of 239 people. There are 139 students aged from 18 to 35 enrolled in Elabuga Institute and studying the following specialities: Native language and literature; Native language and literature, foreign languages. There also were 20 school teachers of the Republic of Tatarstan and more than 80 students of different educational institutions.

The reliability of the research results was determined by the original theoretical and methodological provisions based on fundamental current research in pedagogy, psychology, cultural studies, linguistics, regional studies, the serial implementation of the original theoretical propositions using a set of methods adequate to the subject, tasks, logic, research, personal participation of the author to experimental work and its results, and 


\section{I}

GÊNERO E

INTERDISCIPLINARIDADE

application of methods of mathematical statistics.

\section{Discussion and results}

Modern Russian society sets a number of theoretical and practical tasks for general education organizations related to the education of students in the new conditions of complex interaction between different peoples. Each person bearing a large number of ethnic characteristics and traditional foundations of their people should have a set of personal attitudes, positive tendencies, versatile abilities, universal values that regulate the behavior of people in society, family, work, and in everyday life (Danilova, 2006). These values and priorities are formed in a person first of all in the family, where they receive basic education through the prism of national consciousness and learns the traditions and culture of a particular ethnic or multi-ethnic environment (Lyausheva, 2011; Linell, 2004). Therefore, an important task in the educational process of educational organizations is the use of the educational and educational potential of national cultures, traditions, customs, means of folk pedagogy, as a multicomponent means of forming a tolerant personality by teachers.
$\operatorname{Vol}^{\circ} 02$ | nº 01 | ISSN: 2675-7451

https://www.periodicojs.com.br/index.php/gei/index

Education is generally understood by folk pedagogy as preparation for life in society. In a broader sense, education is the process of passing the things that the society has accumulated to the younger generation. Universal moral values are not subject to time and space. They should accompany a person throughout their lives regardless of external circumstances and social disasters, and dialog is considered as a specific form of social interaction based on equality and freedom of the participants aimed at clarifying, bringing closer and mutually enriching their positions. Other, deep understanding of the dialog, such as 'outsidedness' (Bakhtin, 1989), 'hearing-listetning' (A. U. Kharash), 'the focus on the interlocutor' (A. A. Ukhtomsky), 'frienddominating idea' (Yu. V. Senko), and 'a creative act generated by spiritual individuality' (V. Gumboldt) (Bibler, 1989).

However, it is necessary to recognize the lack of elaboration of the issues of didactic organization and its role in the formation of an active, independent, creative person who is ready to maintain a dialog with representatives of different cultures as a subject of this activity (Bibler, 1993) . 


\section{I}

GENERO E

INTERDISCIPLINARIDADE

'The cultural dialog is an awareness of the uniqueness and belonging of different cultures and cultural diversity as a source of personal and social development, the formation of personality in a multicultural society' (Smirnova, 2012). 'Cultural dialog involves not only humanitarian contacts of national cultures, but also the introduction of an individual to their spiritual world. It is not the cultures themselves that enter into the dialog, but the people, for whom the corresponding cultures draw specific semantic and symbolic boundaries. The implementation of cultural dialog is an introduction to other cultures, other semantic worlds, but not a dissolution into them. Dialog as a principle of cultural development allows not only to organically borrow the best from the world heritage, but also to be counted, to make a personal reinterpretation of 'foreign culture'. The principle of dialogism is understood as openness to other cultural values, their tolerant perception, and the enrichment of world practice with the most significant values of their culture' (Khasanova, 2006).

The basis of human existence and thinking at the end of the $\mathrm{XX}$ century is a dialog, a polylog, a universal way of mastering the spiritual and value
Vol $^{\circ} 02$ | nº 01 | ISSN: 2675-7451

https://www.periodicojs.com.br/index.php/gei/index

foundations of life, a form of searching in the world of universal values: truth, goodness, beauty, love, and happiness. This is both a way of world cognition and a means of self-determination. A person should live in many cultures. Following the modern understanding of dialog, this conscious life is about the dialog of being: to listen and to question, to say goodbye and to doubt, to wonder and admire, to argue and convince.

In this regard, Mikhail Bakhtin wrote: 'The truth is not born and does not reside in the mind of an individual, it is born between people who jointly seek the truth in the process of dialogical communication' (Dialog - based concept of culture by M.M. Bakhtin - V.S. Bibler, n.d.).

Based on this thesis, V. S. Bibler develops his own version: 'Cultures do not have their own territory', 'culture is more fully and deeply disclosed only in the eyes of another culture'. He considers the learning process to be the organization of a cultural dialog, when the 'highest' achievements of human thinking and consciousness enter the dialog with previous forms of culture' (Domansky, 2014; Lange, 1999).

Speaking of a dialog in a literary text, there are several types of it: 1) a dialog of utterances and voices of 


\section{I}

GÊ NERO E INTERDISCIPLINARIDADE

characters; 2) a dialog of meanings and entities, 3) a dialog of personalities (characters and the author), 4) a dialog in the mind of the acting character, narrator, or author.

The first type of dialog is linguistic manipulation, verbal communication of the characters. Their remarks often lack any vital important meanings. This dialog is situational, it occurs spontaneously and ends within the framework of a speech situation. It often is considered as a dialog about nothing (Domansky, 2014).

This study focuses on the work of the famous Tatar writer Razil Valeev as a special cultural phenomenon and its possibilities in the spiritual and moral development of a growing person's personality. The story 'Dog sun' (1968), written by the author while he was a student, starts with a description of a young man who does not find a place in his family, as well as in society. The writer gives a very accurate assessment of society in an image of a madman: 'How pitiless and blind a man is!.. They hide their true identity, so in order to forget their meanness for a moment, to love art, literature, music, a new world, a new person; they worship a deliberate world, deliberate heroes, consider themselves God, call themselves
Vol $^{\circ} 02$ | nº 01 | ISSN: 2675-7451

https://www.periodicojs.com.br/index.php/gei/index

geniuses.' The title of the story has a hidden and at the same time ironic meaning. In the plot, this phrase is often found in childhood memories. After swimming, they came out of the water and called the sun:

Dog sun, go away, go away,

Earth sun, look out! (Valeev, 2000)

The work is based on a widespread situation: this is the relationship of an offended girl (Amina) and a kind-hearted guy (Irek). The title of the work corresponds to the content. 'Dog sun' is understood as the main symbol of the work, which means that the sun covered with shadow is cold and has no heat, and the events in the story are closely related to this symbol. Irek is a student of an institute, he lives in a dormitory. At the institute, a guy named Fayaz rapes a student Amina, and on the second day, a meeting is held on this occasion. By the decision of the meeting, Fayaz is expelled from the institute, and soon becomes imprisoned. This is the first 'dog sun' that lights the girl's soul. At that time, the problems were solved by holding a meeting where all students and teachers participated. Before introducing the reader to the girl, the author describes Irek's childhood. The content of the work 


\section{GÊNERO E}

INTERDISCIPLINARIDADE

contains a hint, a symbolic 'key'. When

Irek was a little boy, he was assigned to take care of fourteen goslings for the whole summer. The mother's intention were pious: to teach her son to work and get the benefit of it: 'If you grow them all up before autumn, I'll make you a pillow out of their feathers.' Mother kept her promise: 'my mother stuffed my pillow with the fluff of thirteen surviving goslings. I had slept on it until I left the village' (Valeev, 2000).

The girl was brought up under the influence of her mother's Communist ideals, so her childhood was not very happy: 'My mother teaches Russian at school. There is nothing more dull than such a life: neither city, nor village. The thirties are dead and gone, but they still don't want to understand that the twentieth century is coming to an end. I'm not complaining about my mother. No. She fed, watered, clothed, warmed me, loved me, and tried to raise me as a modern person' (Valeev, 2000). Amina's mother used to live by her own justice, she accepted the proposed ideological laws of the time without complaint. That is why in her most difficult time, Amina can not share her grief with her mother, but remains lonely. From this viewpoint, her mother is also unhappy. She is a Soviet person who subordinates her life
$\mathrm{Vol}^{\circ} 02 \mid \mathrm{n}^{\circ} 01$ | ISSN: 2675-7451

https://www.periodicojs.com.br/index.php/gei/index

to political and ideological laws. In this image, the author claims that Soviet society had fundamentally wrong attitude to the family. In human life, which was considered a valuable treasure, the family institution was almost destroyed.

The second type of dialog is often the essence of the conflict in this story, it reflects the family and household, sociopolitical, moral-aesthetic, and philosophical conflicts that can be found in the text (Domansky, 2014; Byram, 1989). The story 'The Old clock keeps perfect time' continues to highlight the problems reflected in the 'Dog sun'. Unlike other Valeev's works, the story is unique in its system of images. Here a person is perceived as a tolerant person in a literary work.

The book critic F. Khatipov wrote: 'In literature and art, a type is an image whose individual features embody the most characteristic features of a certain category, group, nationality, or professional affiliation.' Type (typos) is a Greek word meaning imprint, shape, pattern. A representative of a species that combines certain common properties is also called a type. The artistic type is closely related to the typicality in real life...' (Khatipov, 2002). For example, Iskander in R. Valeev's 'The Old clock 


\section{,}

E GENEROE

INTERDISCIPLINARIDADE

keeps perfect time' is a typical image of a representative of the arts society. At the same time, the image of Iskander has its own personality. This is due to his character. 'Character is an individual personality pattern of a person manifested in the features of behavior and attitude to the surrounding reality' (Khatipov, 2002). The main character of the work, Iskander, is a talented musician who did not find himself as a personality. The author describes him as a creative person. His character is complex, inconsistent and interesting, and it differs from the personalities of other characters in the story. The center of the story is the youth looking for their place in life. The main attention is drawn to the image of young people who grew up surrounded by beautiful rural nature under the supervision of their parents, without knowing any worries, as wel as their first encounter with the harsh reality, experiences, contradictory thoughts in their independent life. These 'rushing' characters who have set themselves high hopes are Iskander, Fidan, Hamit, Rudel, Intizar, Alfred, Habir, Hamit's wife, Motigulla, Sagidulla, Ibrahim. Each of them enters into various relationships with the main character - Iskander. The most interesting thing is that the
$\operatorname{Vol}^{\circ} 02$ | nº 01 | ISSN: 2675-7451

https://www.periodicojs.com.br/index.php/gei/index

characters in the story are not described in groups.

The third type of dialog is the dialog of personalities. Each personality can have their own logic, point of view on the world and man, their own system of values. The author, of course, has his own concept of being, but he does not suppress the personality of his characters, although he can enter into a dialog with them (Domansky, 2014; Byram, 1989). The description of people in real life is not limited to these characters. Iskander leaves to find his wife and child. He gets on the first train that goes to the station 'Light path' to find his family: his wife and daughter.

The future of the nation, the fate of youth is very significant in this story. Valeev is interested in the worldviews of the younger generation, their principles of life, dreams, friendship, and love. For example, the story has a number of characters-images: Amina, Syumbel, Zaliya, Nurislam. In these images, the writer wanted to show how widespread immoral phenomena are growing among young people, losing the qualities inherent only in women and girls, pure love, parting with ancient customs.

In the Soviet period, national traditions and moral norms almost lost their significance (Shaimardanov, 2012; 


\section{GÊNERO E}

INTERDISCIPLINARIDADE

Bennett, 1993). Yahya Abdullin wrote:

'The Bolshevik government did everything to separate the people from its heritage, from history. This has crippled us spiritually and caused moral losses. Drinking, drug addiction, indiscipline among young people, and generational inconsistency are just some examples' (Abdullin, 1999).

Razil Valiev's works reflect the same phenomena that are consonant with the environment. The writer shows the situation of young people standing at the bottom of the abyss with the surrounding reality. A good example is a dialog from the work 'The Old clock keeps perfect time'. The conversation begins with Syumbel who behave rude and wild:

- Do you think anyone needs you? Why, if a person comes to you with open arms, does it ever mean that he is ready to give his soul for you? He just wants something from you. If he smiles past his ears it's not because he wants to show his joy in front of the others. When will you get rid of your innocence? Love of themselves is quite enough for a person...' (Valeev, 2000).

The dialog is one-sided: the wife is speaking, the husband is listening, but the fire of the answer is burning inside him. The husband is silent because he
Vol $^{\circ} 02$ | nº 01 | ISSN: 2675-7451

https://www.periodicojs.com.br/index.php/gei/index

knows that then the conversation would end faster.

Unfortunately, this dialog occurred between the newlyweds.

In another young family, the dialog will also be introduced between the husband and wife, and the initiative is in the hands of the husband.

- Where have you been keeping yourself?! Children have strained their eyes, they've never left the window sill!' But she speaks calmly:

- The same place you hang around all hights' (Valeev, 2000).

The husband, of course, wants to punish his wife by beating her with a belt, forgetting that he leaves at nights for his friends to drink. The causes and consequences of all these 'family scenes' can be summarized by the remark of men.

Khamit: - Sometimes heart-toheart talk is more valuable than all life! Why are they making a fuss? I got her an apartment, arranged the furniture, and gave her all my salary. What else do they need? Can't I sit with my friends and bare my heart? (This is an utterance about the wives of Khamit and his interlocutor).

- Have you even told her???

- Yes, why, yes!

- So what? 


\section{1}

GÊNERO E

INTERDISCIPLINARIDADE

- She says: 'I do exactly what you

$d o$. The apartment was not given just for you but for the whole family, I also gave money for furniture. If you want, live here and play it down, if you don't want - you are free to leave to the four winds.

- Did you mention the soul, the soul?

- Hey, buddy, she has the answer ready for all my words, - says Khamit... (Valeev, 2000).

This story realistically describes the irresponsibility of young people in family relationships, inattentiveness in communication, and how all this carelessness in words affects the psyche of the interlocutor.

The dialogs make it clear that these phenomena are not only related to family relationships. The following conversation serves as an example that confirms these thoughts:

Fidan: - Love and happiness are completely different things. Love is short. If you're old and still in a love frenzy, what good are you to people? If you love, do something in the name of it, we live in the real world... If a person could not wake up from the feeling of love all his life, then he would have never found his place in society. One can't wait and watch for happiness, happiness doesn't come by itself, you have to go
$\mathrm{Vol}^{\circ} 02$ | nº 01 | ISSN: $2675-7451$

https://www.periodicojs.com.br/index.php/gei/index

towards happiness, to fight for it and win.

Iskander responds - You mean, just like me? Syumbel tore out of your mouth, and you were left with your mouths open, weren't you?

- Stolen goods won't do any good, - Intizar added fuel to the hot argument.

- The happiness that is meant for you comes by breaking your teeth, - says Khamit splashing water on the fire. Each person has their own happiness. Search, find this happiness, do not try to snatch someone else's one... Find yours... (Valeev, 2000).

This dialog shows that the characters are typical of envy and pushing ways.

Dialog within consciousness, i.e. internal dialog is related to the ability of a person to 'credit' different ways of understanding the world, to collide different points of view, types of logic and thinking in their minds. In other words, internal dialog is a person's ability to say 'You' to themselves. 'Through 'You'a person becomes 'I', that is, he becomes aware of himself as a person, 'sees himself' (Kramsh, 1996).

The novel 'Heritage' describes people of three generations: the old man Ziyatdin, his daughter Magruy, son-inlaw Timerkhan, and Timerkhan's son 


\section{I}

[i GENEROE

INTERDISCIPLINARIDADE

Ikhtiyar. Each of these images characterizes its generation. The author tries to assess the events taking place within the country.

The 'family' of Ikhtiyar and Zaliya restores the family model based on convenience. The girl's consent to marry a guy is due to the fact that 'I will still leave the village guy to live in the city', this is the result of the wanting to be a winner in a girls' argument. When Ikhtiyar leaves to his grandfather in the village, she has not even a slightest interest to him. When Ikhtiyar was named an engineer of the new building, she immediately comes to him. As if nothing had happened, she starts talking about wedding affairs. This wedding turns into a display of the true face of the daughter-in-law: she invites high-class guests, and has a quarrel with Ikhtiyar's parents. Of course, it is not surprising that the family broke up on a second day.

These dialogs are often carried out in a specific text that contains signs, symbols, codes, images, ideas, and
$\mathrm{Vol}^{\circ} 02$ | nº 01 | ISSN: $2675-7451$

https://www.periodicojs.com.br/index.php/gei/index

concepts of certain cultures. Therefore, many outstanding works of art can be read through the prism of these cultural and semantic layers, thanks to which the work functions in the 'big' time. These cultural and semantic layers are set by the author by a variety of means: introduction of plots into the text, as well as micro-plots, motives, images, quotes, mythologisms related to various cultural texts, as well as information from philosophy, ethics, social science and politics, religious teachings (Shevchenko, 2017; Khairullina, 2017).

The final sections at the control stage of the experiment dealt with evaluating the efficiency of the implementation of pedagogical conditions and identifying the degree of tolerance in students. The cross-sections were performed using the same diagnostic tools as at the ascertaining stage of the experiment. The results of the survey of students' tolerance in the control and experimental groups are presented in the table.

Table 1. Distribution of students by level of formedness of tolerance before and after the experiment

\begin{tabular}{|l|c|c|}
\hline \multirow{2}{*}{ Levels } & Control group & Experimental group \\
\cline { 2 - 3 } & Criteria & Criteria \\
\hline
\end{tabular}


$\mathrm{Vol}^{\circ} 02$ | n $^{\circ} 01$ | ISSN: 2675-7451

https://www.periodicojs.com.br/index.php/gei/index

INTERDISCIPLINARIDADE

\begin{tabular}{|c|c|c|c|c|c|c|c|c|c|c|c|c|}
\hline & \multicolumn{2}{|c|}{$\begin{array}{l}\text { Cognitive } \\
(139 \text { people } \\
\text { in } \%)\end{array}$} & \multicolumn{2}{|c|}{$\begin{array}{l}\text { Motivational-- } \\
\text { value }(80 \\
\text { people in } \%)\end{array}$} & \multicolumn{2}{|c|}{$\begin{array}{l}\text { Operational- } \\
\text { activity-based } \\
(20 \text { people in } \\
\%)\end{array}$} & \multicolumn{2}{|c|}{$\begin{array}{l}\text { Cognitive } \\
(139 \text { people } \\
\text { in \%) }\end{array}$} & \multicolumn{2}{|c|}{$\begin{array}{l}\text { Motivation } \\
\text { al-value }(80 \\
\text { people in } \%)\end{array}$} & \multicolumn{2}{|c|}{$\begin{array}{l}\text { Operation } \\
\text { al-activity- } \\
\text { based (20 } \\
\text { people in \%) }\end{array}$} \\
\hline & before & after & before & after & before & after & before & after & before & after & before & after \\
\hline Low & 10.34 & 12.2 & 25.73 & 28.6 & 11.34 & 14.07 & 20.48 & 25.6 & 33.28 & 37.08 & 15.36 & 23.2 \\
\hline Medium & 24.14 & 25.9 & 24.14 & 25.1 & 31.46 & 31.46 & 27.59 & 38.2 & 30.87 & 34.60 & 40.96 & 48.64 \\
\hline High & 65.52 & 61.9 & 50.13 & 46.3 & 57.2 & 54.47 & 51.93 & 36.2 & 35.85 & 28.32 & 43.68 & 28.16 \\
\hline
\end{tabular}

The study deepens and specifies the scientific ideas about the essence of the formation of a tolerant personality in students through cultural dialog in the aspect of culture of interethnic communication and personal identification in society and family. It also defines the types, models, content, forms, and methods of forming a tolerant personality in students, as well as factors and conditions of a tolerant environment. The paper highlights the components and the regional specificity of the formation of tolerant personality. Theoretical developments and approaches of foreign researchers were adapted to the conditions of the Russian education system in forming a tolerant personality.
The data and presented materials can be used by teachers of higher and secondary professional educational institutions, schoolteachers, specialists of the system of further education of education workers, in the development and implementation of the content of professional training of students to form their tolerance, to enrich the courses in specialities: 'General pedagogy', 'Theory of learning and pedagogical technologies', 'Theory and methodology of education', and 'National pedagogy'. The scientific value of the research complements the theoretical space of the actual pedagogical problem, makes it possible to consider the results of the work from the practical point of view. Its practical significance lies in the fact that the proposed model can be used by teachers at 


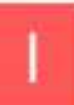

GÊNERO E

INTERDISCIPLINARIDADE

lessons of national pedagogy, native literature and extracurricular activities for educational work.

\section{Conclusion}

The considered dialogs are typical for educational dialogs, which should become the main way of being in the classroom today. Dialogical assimilation of culture allows a person to perceive the world as a whole, experiencing, comprehending, realizing their connection with the present, past and future, their belonging to the integrity of spiritual culture. Declaring these important meanings, the special attention should be paid to the pedagogical technology of a cultural dialog.

Dialogic interaction in the learning process is designed to actualize tolerance as a system quality, improves its development, influences the motivational sphere of students' cognitive activity, activates the processes of self-realization and reflection. In turn the latter actualize the tendency to plan learning as a creative process that is not reduced to the development of ready-made rules for solving various tasks. Adopted as a basis, the idea of dialog provides a subjective position of students in the educational process, actualizes their communication skills and respect for people and their judgments and manifestations, as well as tolerance and delicacy in interacting with others, develops critical thinking, reflection
Vol $^{\circ} 02$ | nº 01 | ISSN: 2675-7451

https://www.periodicojs.com.br/index.php/gei/index

and self-reflection. The level of development of tolerance in students and schoolchildren directly depends on the level of development of dialogic skills. This idea is the key to the development of tolerance among school and university students.

\section{Conclusion:}

Having reviewed the stories 'Dog sun' and 'The Old clock keeps perfect time' and the novel 'Heritage' by Razil Valeev, the conclusion is: it is possible to form character and tolerant personality through the literary characters' cultural dialog. Modern education should be carried out by forming morality and culture in each person - a capable person to create a cultural space of life.

Thus, cultural dialog is a means of spiritual and moral education of a tolerant person that accumulates rich ideas and experience of older generations. The study and development of the historical experience of the people and the treasures of their spiritual culture and literary heritage carried through the centuries and millennia are of paramount importance for the modern young generation.

\section{Acknowledgements}

The study was performed in accordance with the state program for improving the competitiveness of Kazan Federal University. 


\section{1}

GÊNERO E

INTERDISCIPLINARIDADE

\section{References}

Abdullin, Ya., 1999. The fate of nation. Kazan': Nauka.

Alviar-Martin, T., Randall, J. D., Usher, E. L., Engelhard, G., 2010. Teaching Civic Topics in Four Societies: Examining National Context and Teacher Confidence. The Journal of Educational Research 101 (3), 177-188.

Bennett, M., 1993. Towards ethno relativism: a development of model of intercultural sensitivity. In: Education for the intercultural experience. Yarmouth, ME: Intercultural Press, 21-71.

Bibler, V. S., 1989. Dialog, consciousness, culture (The idea of culture in the works of M.M.Bakhtin). Moscow.

Bibler, V. S., 1993. Cultural dialog and school of the XXI century. In: Shkola dialoga kul'tur: Idei. Opyt. Problemy. Kemerovo.

Byram, M., 1989. Cultural studies in foreign language education. Clevedon, Avon: Multilingual matters LTD.

Danilova, S. V., 2006. On the role of dialog in the educational process. In: Tsennostnosmyslovye orientatsii i strategii upravleniya razvitiem obrazovatel'nykh uchrezhdeniy: proceedings of All-Russian research and methodology conference 'Chetvertye Cheredovskiye chteniya'. Omsk: Izd-vo OmGPU.

Dekker, S., Fischer, R., 2010. Cultural Differences in Academic Motivation Goals:
$\mathrm{Vol}^{\circ} 02$ | nº 01 | ISSN: $2675-7451$

https://www.periodicojs.com.br/index.php/gei/index

A Meta-Analysis Across 13 Societies. The Journal of Educational Research 102 (2), 99110.

Dialog - based concept of culture by M.M. Bakhtin - V.S. Bibler. URL: http://www.countries.ru/library/rusidea/ribb. $\underline{\mathrm{htm}}$

Domansky, V. A., 2014. Cultural dialog and dialog in culture in studying literature. Vestnik Sankt-Peterburgskogo universiteta, ser. 12, 4, Pedagogicheskaya psikhologiya, 106-110.

URL:

https://cyberleninka.ru/article/n/dialog-

kultur-i-dialog-v-kulture-pri-izucheniiliteratury

Khairullina, A. S., 2017. The image of the mother and her role in moral education in students (the example of works of Tatar writers). Education, Science and Humanities Academic Research Conference: Conference Proceedings, June 30 th, 2017, San Francisco, USA: Scientific public organization 'Professional science'. URL: http://docplayer.ru/73709217-Educationscience-and-humanities-academic-research$\underline{\text { conference.html }}$

Khasanova, L. I., 2006. Formation of the student's personality as a subject of the cultural dialog in educational activities.. Extended ebstract of candidate dissertation. UdGU, Izhevsk.

Khatipov, F., 2002. Theory of literature: study guide for students of universities and 


\section{।}

E GÊnero e

INTERDISCIPLINARIDADE

colleges. Kazan': Rannur.

Kramsh, K., 1996. Context and culture in language teaching. Hong Kong: Oxford University Press.

Lange, D. L., 1999. Planning for and using the new national culture standards. Foreign language standards: linking research, theories and practices. Lincolnwood, IL: National Textbook company.

Linell, P., 2004. On same Principles of a Dialogical grammar. In: Dialogue Analysi s VIII: Understanding and Misunderstanding in Dialogue. Selected Papers from 8-th IADA. Conference. Goeteborg. Tubingen: Niemeyer.

Lyausheva, S. A., 2011. Education of a tolerant personality in the context of intercultural dialog. Vysshee obrazovaniye $\mathrm{v}$ Rossii 2, 82-88.

Smirnova, A. G., 2012. Formation of a tolerant personality by means of culture: cultural aspect. Problemy sovremennoy nauki 4, 25-46.

Shaymardanov, R. Kh., 2012. The role of the native language in the formation of the national identity of the younger generation. Proceedings of $\mathrm{X}$ Yugorskie readings 'Korennye malochislennye narody Severa, Sibiri i Dal'nego Vostoka: traditsii i innovatsii'. Khanty-Mansiysk: OAO 'Informatsionno-izdatel'skiy tsentr'.

Shevchenko, T. P., 2017. Formation of valuesemantic attitude of students to multicultural
Vol $^{\circ} 02$ | nº 01 | ISSN: 2675-7451

https://www.periodicojs.com.br/index.php/gei/index

dialog in the educational environment of the university. KGPU: Kazanskiy pedagogicheskiy universitet.

Valiev, R., 2000. Selected: Novel and stories. In 4 volumes. Vol. 2. Kazan: Natsional'naya kniga.

Vasil'eva, A. A., n.d. Formation of a student's tolerant personality by means of a foreign language in a multicultural university environment. URL: $\underline{\text { http://tggpu.ru }}$

Webster, J. W., 2010. Effects of Ninth Graders' Culture-Specific Schemata on Responses to Multicultural Literature. The Journal of Educational Research 95 (1), 1225. 